\title{
Application of Chitosan-Clay Biocomposite Beads for Removal of Heavy Metal and Dye from Industrial Effluent
}

\author{
Shanta Biswas ${ }^{1, * \mathbb{C}}$, Taslim Ur Rashid ${ }^{1,2, * \mathbb{C}}$, Tonmoy Debnath ${ }^{1}$, Papia Haque ${ }^{1}$ and \\ Mohammed Mizanur Rahman 1,3,* \\ 1 Department of Applied Chemistry and Chemical Engineering; University of Dhaka, Dhaka 1000, \\ Bangladesh; tonmoy.ac33@gmail.com (T.D.); papiahq@du.ac.bd (P.H.) \\ 2 Fiber and Polymer Science, North Carolina State University, Campus Box 7616, Raleigh, NC 27695, USA \\ 3 National Institute of Textile Engineering and Research, Nayarhat, Savar, Dhaka 1000, Bangladesh \\ * Correspondence: shanta@du.ac.bd (S.B.); turashid@ncsu.edu (T.U.R.); mizanur.rahman@du.ac.bd (M.M.R.); \\ Tel.: +880-1672430024 (S.B.); +1-919-7803269 (T.U.R.); +880-1710417260 (M.M.R.)
}

Received: 30 December 2019; Accepted: 20 January 2020; Published: 1 February 2020

check for updates

\begin{abstract}
In recent years, there has been increasing interest in developing green biocomposite for industrial wastewater treatment. In this study, prawn-shell-derived chitosan (CHT) and kaolinite rich modified clay (MC) were used to fabricate biocomposite beads with different compositions. Prepared composite beads were characterized by FTIR, and XRD, and SEM. The possible application of the beads was evaluated primarily by measuring the adsorption efficiency in standard models of lead (II) and methylene blue (MB) dye solution, and the results show a promising removal efficiency. In addition, the composites were used to remove $\mathrm{Cr}(\mathrm{VI}), \mathrm{Pb}$ (II), and $\mathrm{MB}$ from real industrial effluents. From tannery effluent, $50.90 \%$ of chromium and $39.50 \%$ of lead ions were removed by composites rich in chitosan and $31.50 \%$ of $\mathrm{MB}$ was removed from textile effluent by a composite rich in clay. Moreover, the composite beads were found to be activated in both acidic and basic media depending on their composition, which gives a scope to their universal application in dye and heavy metal removal from wastewater from various industries.
\end{abstract}

Keywords: chitosan; Bijoypur clay; biocomposite; heavy metal; chromium (VI); lead (II); methylene blue dye; tannery effluent; textile effluent

\section{Introduction}

In modern times wastewater released from industries is a major concern for environmentalists. Industrial effluents contain various toxic metals, harmful gases, and many organic and inorganic compounds. The discharge of these untreated toxic effluents has deteriorated natural flora and fauna and causes a risk to human health. A human who is exposed to such an environment in the long term can be attacked by fatal diseases like cancer, delayed nervous responses, mutagenic changes, and neurological disorders, etc. [1]. Thus, there is a current demand to maintain the standard permissible limit of such elements in industrial effluents before discharge to the environment. Hence, a fair number of physical, chemical, and biological methods have been employed to embark upon the problem of the removal of these materials from wastewater [2-8]. Compared to many expensive techniques, adsorption is preferred due to its flexibility, compatibility, low cost, and regeneration ability [9-11]. Considering the recent trends in attaining environmental sustainability, scientists are concentrating on utilizing naturally available materials to produce low-cost green adsorbents for the efficient removal of hazardous materials from wastewater [12,13]. 
Chitosan, obtained from chitin, is a relatively inexpensive material as chitin is the second most abundant polymer in nature next to cellulose $[14,15]$. It has shown many potential applications in the fields of wastewater treatment [14,16,17], tissue engineering [18], agriculture [19,20], biomedicine [21], drug delivery [22], and so on. Chitosan can be extracted from the exoskeletons of crustacean fungi and some insects. Bangladesh exports large quantities of shrimp/prawn every year. The respective processing plants produce large quantities of shells that remain unused and become treated as waste, showing no potential scope for profitability or reuse. In addition, these shells generate another issue for environmental pollution. Hence, waste prawn shells could be a good source of chitosan extraction. A large and growing body of literature has investigated the use of chitosan for heavy metal and dye removal from industrial effluents $[17,23]$. One major drawback of this approach is that chitosan is dissolved under acidic conditions, while several metals are preferentially adsorbed in acidic media. Researchers have attempted to solve this problem by incorporating chitosan into other materials that could improve its performance under a wide range of environmental conditions [24].

Recent research has revealed clay minerals as a natural inorganic material with definite structural adsorption, rheological, and thermal properties [25]. These materials originally have a hydrophilic character due to the presence of their surface hydroxyl $(-\mathrm{OH})$ groups which can link water molecules very easily [26]. Clay mineral has a long enchanting history of metal binding [25], dye removal [27], and fruit packaging [28], while being used independently or combined with other natural or synthetic polymers. However, it is sometimes necessary to purify and modify clay for better compatibility with other polymers [29].

In our previous studies, we developed a biocomposite, both in film form and bead form, based on chitosan and modified Bijoypur clay, and evaluated adsorption isotherms and efficiency for chromium (VI) removal from a standard water model $[24,30]$. The results suggested better adsorption performance for the bead form compared to the film form of the composites. Hence, in the present study, we attempt to fabricate chitosan (CHT)-modified clay (MC) biocomposite beads and evaluate their applicability in removing $\mathrm{Pb}(\mathrm{II})$ and methylene blue dye from a standard model solution. In addition, as a preliminary study, the efficiency performance of these composites for removing $\mathrm{Cr}$ (VI), $\mathrm{Pb}$ (II), and methylene blue (MB) from two real industrial effluents (tannery and textile effluents) is investigated.

\section{Experiments}

\subsection{Materials}

Waste prawn shell was collected from the local hatchery of Satkhira district, Khulna division, Bangladesh. Bijoypur clay was collected from Netrokona, Bangladesh (supplied by Bangladesh Insulator and Sanitaryware Factory (BISF), Dhaka, Bangladesh). Sodium hydroxide, ethanol, and acetic acid were supplied by E. Merck, Germany; hydrochloric acid, methylene blue dye, Pb (II) salt, nitric acid, and sulfuric acid, etc., were collected from Merck KGaA 64271, Dastadt, Germany. Sigma-Aldrich, Stockholm, Sweden, supplied the clay modifying agent dodecylamine. Chromium (VI) salt was collected from Loba Chemie Pvt. Ltd., Mumbai, India. Tannery and textile effluents were collected from industries located in Dhaka city.

\subsection{Methods}

\subsubsection{Extraction of Chitosan from Waste Prawn Shell}

CHT was extracted from the waste prawn shell by following a modified version of the method of Rashid et al. [31]. Dried prawn shell was washed with hot water several times and dried in an oven. The sample was deproteinated with $4 \%(\mathrm{w} / \mathrm{w}) \mathrm{NaOH}$ solution followed by demineralization with $3 \mathrm{~N} \mathrm{HCl}$ to obtain chitin. The chitin was then deacetylated by $50 \%(\mathrm{w} / \mathrm{w}) \mathrm{NaOH}$ at $80-100{ }^{\circ} \mathrm{C}$ to produce chitosan. 


\subsubsection{Purification and Modification of Bijoypur Clay}

Raw Bijoypur clay was screened through a 150-mesh screen and then purified with concentrated hydrochloric acid to remove unbound silica and other impurities. The purified clay was modified by dodecylamine to facilitate the interaction of chitosan with clay and then used in the biocomposite fabrication as MC [32].

\subsubsection{Fabrication of Biocomposite Beads}

Following the method described by Wang et al. and Biswas et al., biocomposite beads of the MC and CHT were prepared [30,33]. At first, $1 \%$ CHT solution (in 1\% acetic acid solvent) and $1 \% \mathrm{MC}$ dispersion (in $1 \%$ acetic acid solvent) were mixed at various amounts (by weight) at a temperature of $60{ }^{\circ} \mathrm{C}$ to form a concentrated homogeneous mixture (Table 1). The mixture was then transferred, in small droplets, into a mixture (1:4) of $15 \%(\mathrm{w} / \mathrm{w})$ sodium hydroxide and $95 \%(\mathrm{w} / \mathrm{w})$ ethanol. Small beads were formed and decanted from the liquid. The separated beads were dried at $60^{\circ} \mathrm{C}$ for $24 \mathrm{~h}$. A detailed fabrication process of the composite is illustrated in Figure 1.

Table 1. Three different composite formulations with different weight ratios of chitosan (CHT) and MC.

\begin{tabular}{cccc}
\hline $\begin{array}{c}\text { Biocomposite } \\
\text { (by Weight) }\end{array}$ & Sample ID & $\begin{array}{c}\text { CHT (\% wt.) } \\
\text { in 1\% Acetic Solution }\end{array}$ & $\begin{array}{c}\text { MC (\% wt.) } \\
\text { in 1\% Acetic Solution }\end{array}$ \\
\hline CHT-MC (2:1) & SB-1 & 1.50 & 0.33 \\
CHT-MC (1:1) & SB-3 & 0.50 & 0.50 \\
CHT-MC (1:2) & SB-5 & 0.33 & 1.50 \\
\hline
\end{tabular}

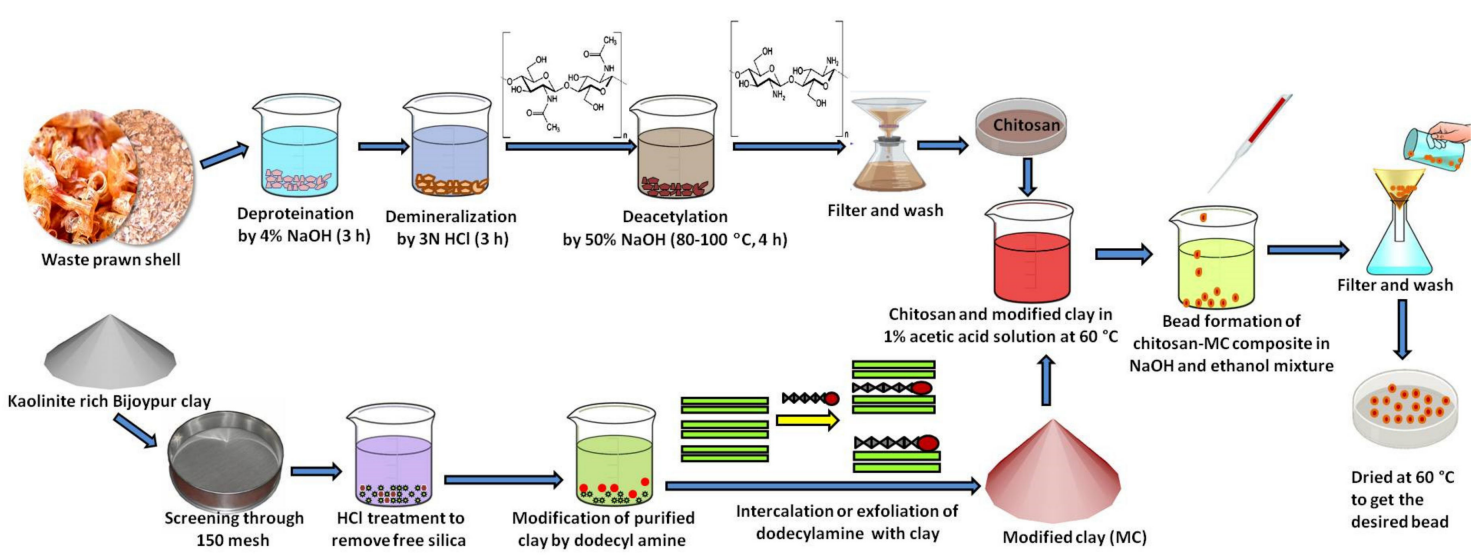

Figure 1. Schematic diagram of fabrication of chitosan-modified clay biocomposite beads.

\subsubsection{Characterization of Biocomposite Beads}

The composite beads (SB-1, SB-3, and SB-5) were examined using an FTIR spectrophotometer (8400S spectrophotometer, Shimadzu Corporation, Kyoto, Japan) to investigate the interaction between chitosan and modified clay, which helps to develop the composite structure. An XRD (BRUKER AXS Diffractometer D8, Karlsruhe, Germany) analyzer was used to obtain preliminary information about the presence of chitosan and modified clay in the composite beads from their crystalline natures. Surface morphology of the raw clay, acid-treated clay, modified clay, and composite beads was compared by SEM (JSM-6490). Detailed descriptions of all of these experimental methods have been reported in our previous article [24].

\subsubsection{Adsorption Studies for Standard Solution and Industrial Effluents}

A stock solution of $100 \mathrm{ppm}$ was separately prepared for each of $\mathrm{Pb}$ (II) and MB. After diluting the stock solution to $25 \mathrm{ppm}, 20 \mathrm{~mL}$ was taken in Erlenmeyer flasks with $0.05 \mathrm{~g}$ of biocomposite 
adsorbent and agitated at $27^{\circ} \mathrm{C}$ on a reciprocating shaker at a fixed rate of $180 \mathrm{rpm}$ for $2 \mathrm{~h}$. The $\mathrm{pH}$ was adjusted to 6 for $\mathrm{Pb}$ (II) and 9.1 for $\mathrm{MB}$ by adding $0.1 \mathrm{~N} \mathrm{NaOH}$ solution, keeping all other parameters constant. MB concentration after and before the removal was determined by a UV-visible spectrophotometer (Shimadzu $1700 \mathrm{UV}$, Kyoto, Japan) by proper calibration $\left(\lambda_{\max }=663 \mathrm{~nm}\right)$, whereas an atomic absorption spectrophotometer (AAS) (Varian AA 240 FS) was used for determination of the $\mathrm{Pb}$ (II) concentration by fixing the wavelength at $283.3 \mathrm{~nm}$. In every aspect, the following equation (Equation (1)) was employed to determine the adsorption capacity, i.e.,

$$
\mathrm{q}_{\mathrm{e}}=\left(\mathrm{C}_{\mathrm{o}}-\mathrm{C}_{\mathrm{e}}\right) \mathrm{V} / \mathrm{W}
$$

where $\mathrm{q}_{\mathrm{e}}$ is the amount of the species $\left(\mathrm{Pb}(\mathrm{II})\right.$ or $\mathrm{MB}$ ) adsorbed $(\mathrm{mg} / \mathrm{g})$ by the adsorbent, $\mathrm{C}_{\mathrm{o}}$ is the initial concentration of the solution $\left(\mathrm{mgL}^{-1}\right), \mathrm{C}_{\mathrm{e}}$ is the final (in some cases equilibrium) concentration of the species solution ( $\mathrm{mgL}^{-1}$ ) after $2 \mathrm{~h}$ of contact, $\mathrm{V}$ is the volume of the solution used (in liters), and $\mathrm{W}$ is the weight of the adsorbent used (in grams).

In the case of the tannery and textile effluents, the samples were digested by concentrated nitric acid and diluted to adjust to the concentration range of the instrument [34,35]. Adsorption studies for $\mathrm{Cr}(\mathrm{VI}), \mathrm{Pb}$ (II), and MB present in the samples were performed using the same procedure followed for standard solution.

\section{Results}

\subsection{Characterization of Biocomposite Beads}

\subsubsection{FTIR Analysis}

The composite fabrication starts with chitosan extraction and clay modification. The conversion of chitin to chitosan is a sophisticated task that requires extra attention at the deacetylation step. Moreover, modification of clay requires sophisticated handling of materials under certain conditions. Successful extraction of chitosan, modification of clay, and fabrication of the composite film were confirmed by detailed FTIR analysis, as discussed in our previous work [24]. However, in this work, the fabrication of the three composites (SB-1, SB-3, and SB-5) in bead form was analyzed by FTIR. While studying the FTIR spectra of the composites, the characteristic peaks of chitosan (at $1601 \mathrm{~cm}^{-1}$ (N-H bending) and $3402 \mathrm{~cm}^{-1}(\mathrm{O}-\mathrm{H}$ stretching overlapping the $\mathrm{N}-\mathrm{H}$ stretching of primary amine) and modified clay (at approximately $2900 \mathrm{~cm}^{-1}$ for $\mathrm{C}-\mathrm{H}$ stretching of dodecylamine in MC) were observed, which confirmed the existence of these two components in the composites (Figure 2). The changes in intensities observed at these three peak positions support the corresponding ratio of chitosan and $\mathrm{MC}$ in the three composites. Moreover, the red shifts of the peak for N-H bending (from $1638 \mathrm{~cm}^{-1}$ in pure chitosan to $1601 \mathrm{~cm}^{-1}$ in the composite) and the peak for overlapping of $\mathrm{O}-\mathrm{H}$ stretching and the N-H stretching of the primary amine (from $3448 \mathrm{~cm}^{-1}$ in pure chitosan to $3402 \mathrm{~cm}^{-1}$ in the composite) indicate the possible interaction between functional groups of $-\mathrm{NH}_{2}$ and $-\mathrm{OH}$ with the -OH of MC. All other important groups from CHT and MC were observed in the FTIR spectra of the composites, resulting in a comparable interaction of the elements. However, it is also noticeable that the FTIR spectra for the bead form composite is similar to that of film form composites (presented in our previous study [24]). 


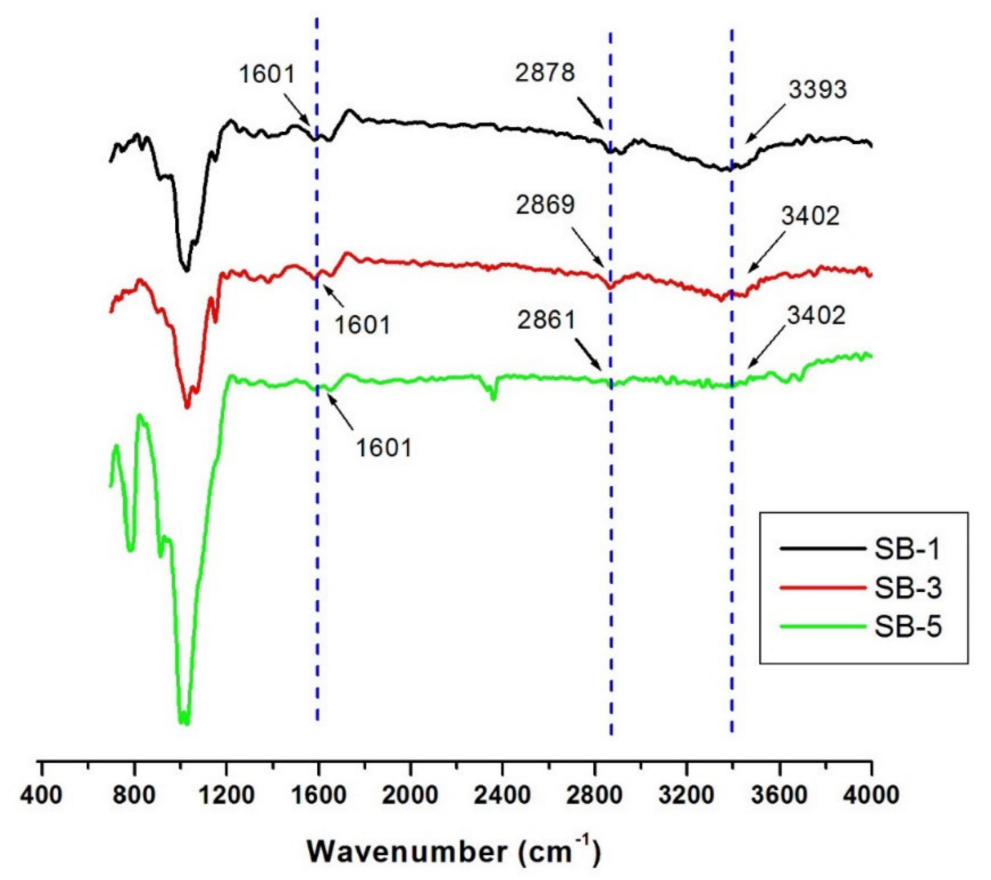

Figure 2. FTIR spectra of biocomposite beads SB-1, SB-3, and SB-5.Transmittance peaks at $1601 \mathrm{~cm}^{-1}$ ( $\mathrm{N}-\mathrm{H}$ bending) and $3402 \mathrm{~cm}^{-1}(\mathrm{O}-\mathrm{H}$ stretching overlapping the $\mathrm{N}-\mathrm{H}$ stretching of the primary amine) indicate the presence of chitosan in the composite while the peak at $2900 \mathrm{~cm}^{-1}$ (C-H stretching of dodecylamine) is due to the presence of MC. Peak intensities at $1601 \mathrm{~cm}^{-1}$ and $3402 \mathrm{~cm}^{-1}$ increase with increasing chitosan content in composite (SB-3 to SB-1).

\subsubsection{XRD Analysis}

Comparative XRD analyses of the chitosan, raw clay, and composites were performed to obtain preliminary information about the presence of chitosan and modified clay in the composite beads (Figure 3). Chitosan has a semi-crystalline nature and clay is very crystalline. However, the observed composite XRD data showed in-between crystallinity, indicating that each component was well-dispersed within the composite system. The results observed from the XRD pattern of the composites reveal that after addition of chitosan into the MC, a peak at $40^{\circ}$, a characteristic peak of kaolinite, disappeared in all the composites. Moreover, a broadening and shifting of another peak at $20^{\circ}$, responsible for clay, was also observed. We assume this was because of the presence of chitosan, which interrupted the overall crystallinity of the clay. 


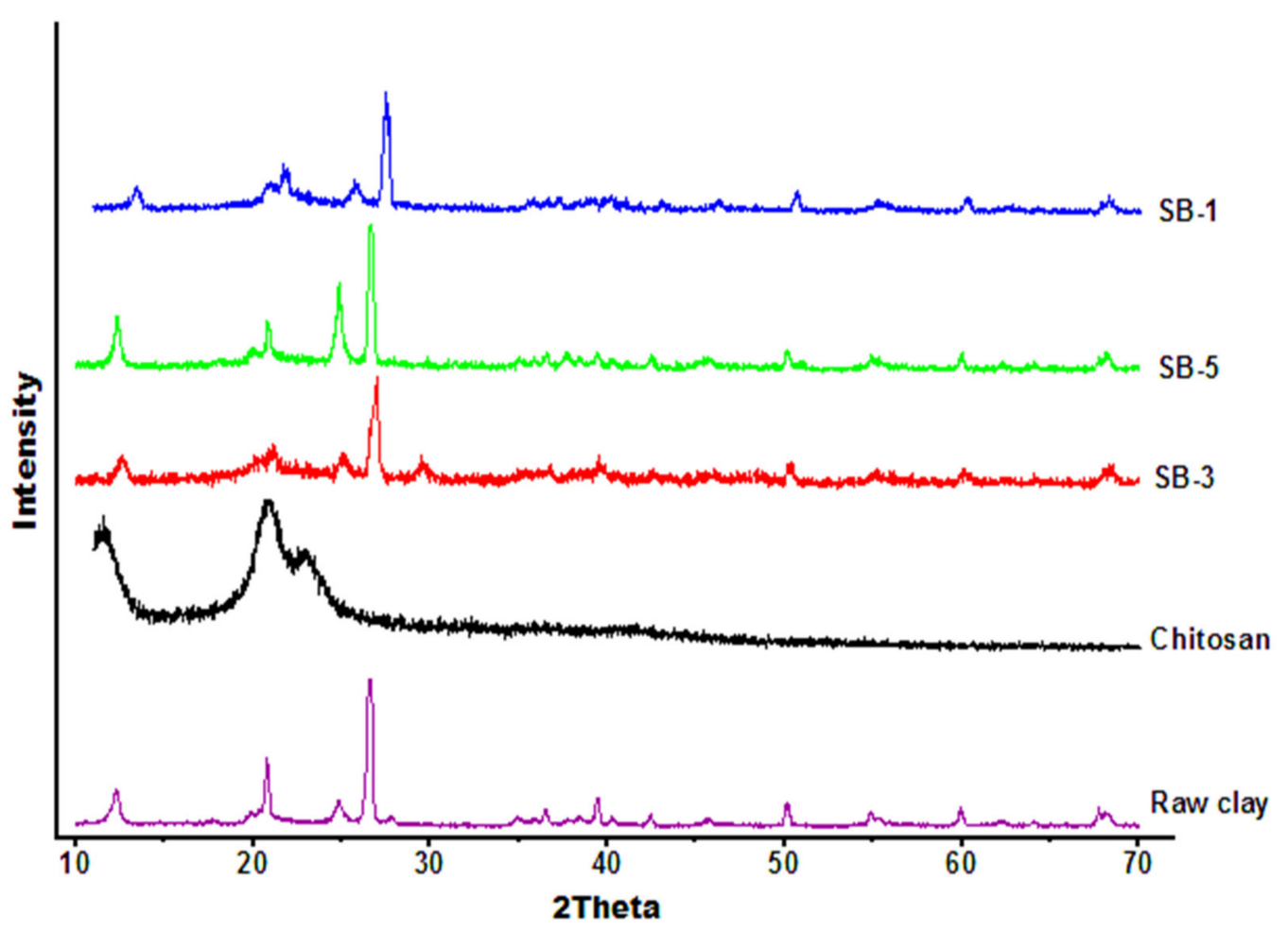

Figure 3. Comparison of XRD data of raw clay, chitosan, and composites (SB-1, SB-3, and SB-5).

\subsubsection{SEM Analysis}

The morphologies of the raw clay, acid-treated clay, modified clay and composites (SB-1 and SB-5) were evaluated by SEM images at $\times 1000$ magnification (Figures 4 and 5). In Figure 4 , the crystalline nature of the clay can be observed in the image of the raw clay, whereas a clear image of the acid-treated clay (purified clay) reveals the removal of unbound silica and other impurities incorporated into the raw clay with clay minerals [24]. In the last image of Figure 4, in modified clay, smooth but discrete spherical particles can be observed that confirm the incorporation of the organic modifying agent into the inorganic clay materials.

In Figure 5, two SEM micrographs of composite samples SB-1 and SB-5 are shown at $\times 1000$ magnification. As SB-1 contains a higher percentage of chitosan, a comparatively smooth surface can be seen. In contrast, SB-5 possesses a relatively rough surface due to a lower percentage of CHT and a higher percentage of MC.

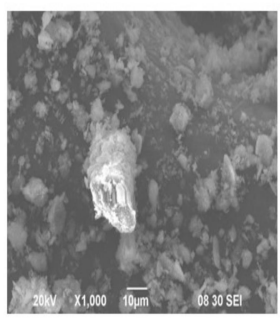

A

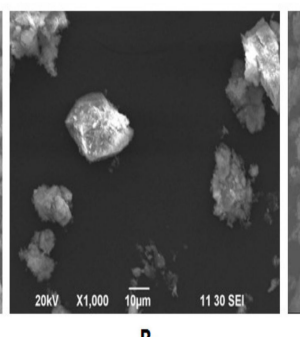

B

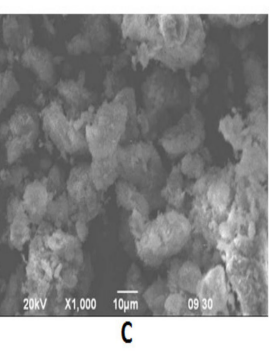

Figure 4. SEM images of (A) Raw clay at $\times 1000$ magnification, (B) purified clay at $\times 1000$ magnification, and $(\mathbf{C}) \mathrm{MC}$ at $\times 1000$ magnification. 


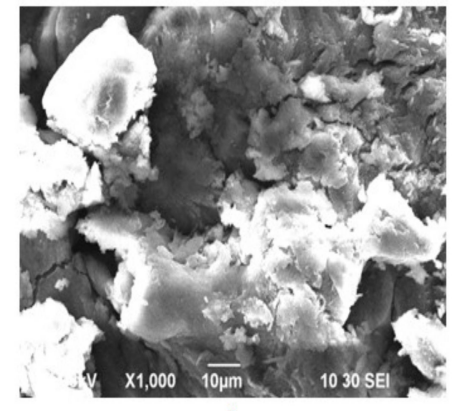

A

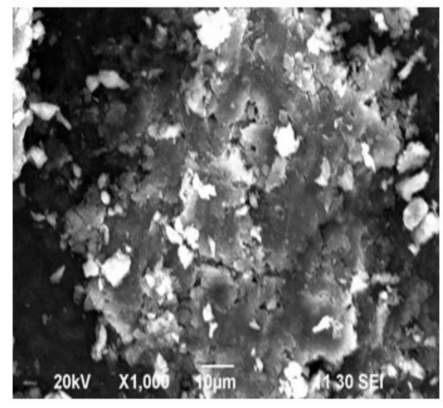

B

Figure 5. SEM images of composite SB-1 (A) at $\times 1000$ magnification and composite SB-5 (B) at $\times 1000$ magnification.

\subsection{Comparative Adsorption Studies on a Standard Solution}

The details of the adsorption technique used, including the isotherm of chromium (VI) from standard solution, have been discussed in our previous work [30]. Better adsorption of $\mathrm{Cr}$ (VI) ions on the SB-1 composite was observed because of the presence of a higher amount of chitosan in the SB-1 samples compared to SB-3 and SB-5 (Table 2). The electrostatic interaction between the $\mathrm{Cr}_{2} \mathrm{O}_{7}{ }^{2-}$ ions (a form of $\mathrm{Cr}(\mathrm{VI})$ in the acidic solution) and $\mathrm{NH}_{3}{ }^{+}$(a form of an amine group of chitosan under acidic conditions) helped ensure a higher uptake of chromium by SB-1 from the solution. In SB-5, meanwhile, the percentage of clay was higher than that of chitosan, and fewer free amine sites were available for adsorbing chromium.

Table 2. Determination of adsorption capacities of composite beads for $\mathrm{Cr}$ (VI), $\mathrm{Pb}$ (II), and MB from their standard solutions.

\begin{tabular}{cccccccc}
\hline \multirow{2}{*}{ Adsorbate } & \multicolumn{5}{c}{ Adsorption Capacities for Adsorbents (mg/g) } & \multirow{2}{*}{$\begin{array}{c}\text { Best } \\
\text { Adsorbent }\end{array}$} \\
\cline { 2 - 6 } & Chitosan & Raw Clay & Modified Clay & SB-1 & SB-3 & SB-5 & \\
\hline $\mathrm{Cr}(\mathrm{VI}){ }^{*}$ & 3.98 & 2.23 & 3.45 & $\mathbf{7 3}$ & $\mathbf{6 4}$ & 49 & SB-1 [30] \\
$\mathrm{MB}$ & 1.01 & 1.30 & 1.83 & 1.682 & 1.95 & $\mathbf{2 . 3 8 5}$ & SB-5 \\
$\mathrm{Pb}(\mathrm{II})$ & 5.184 & 2.632 & 3.86 & $\mathbf{5 . 5 5}$ & 5.052 & 4.032 & SB-1 \\
\hline
\end{tabular}

* Optimized for maximum adsorption.

Being a cationic dye, MB was adsorbed in the highest amount on composite SB- 5 compared to $\mathrm{CHT}, \mathrm{MC}$, and the other two composites (Table 2) (Figure 6). The lowest adsorption capacity was observed for SB-1. The better adsorption of MB by SB-5 is attributed to the cationic nature of MB and the anionic nature of the clay-rich composite in alkaline solution. The $-\mathrm{NH}_{2}$ of chitosan in basic solution became neutral and in acidic media, it became positively charged $\left(\mathrm{NH}_{3}{ }^{+}\right)$. Hence, cationic dye adsorption on chitosan is believed to be lowered due to the absence of any interaction between the $-\mathrm{NH}_{2}$ and dye in solution. However, the presence of an -OH group in chitosan might result in some adsorption of $\mathrm{MB}$, which was lower than the -OH group in clay. In SB-5, the amount of clay was higher than that of chitosan, and hence more anionic -OH clay sites were available for dye adsorption, in addition to the rough surface structure of the bead. In SB-1 the amount of chitosan was higher and, resulting in poor adsorption of methylene blue. A similar kind of phenomenon has been documented by many other researchers over the last decade [36-38]. A schematic diagram of the mechanism of MB adsorption by composite beads is depicted in Figure 7. 


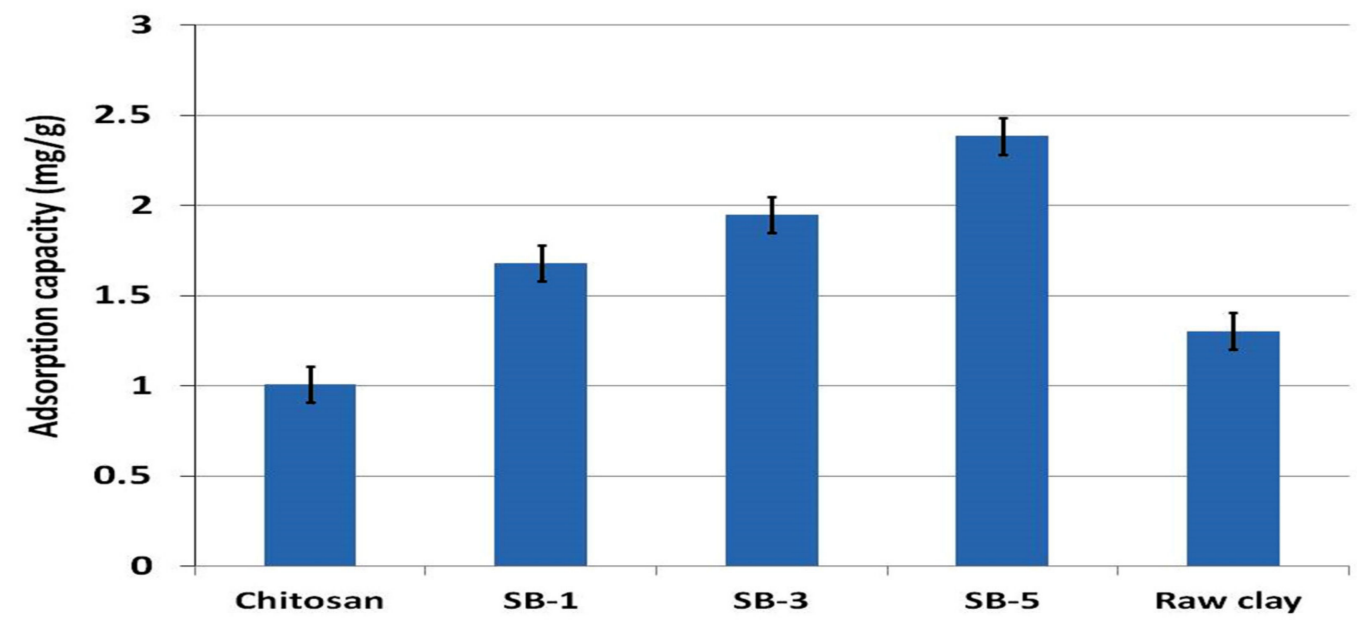

Figure 6. Methylene blue dye removal from standard solution by adsorbents.

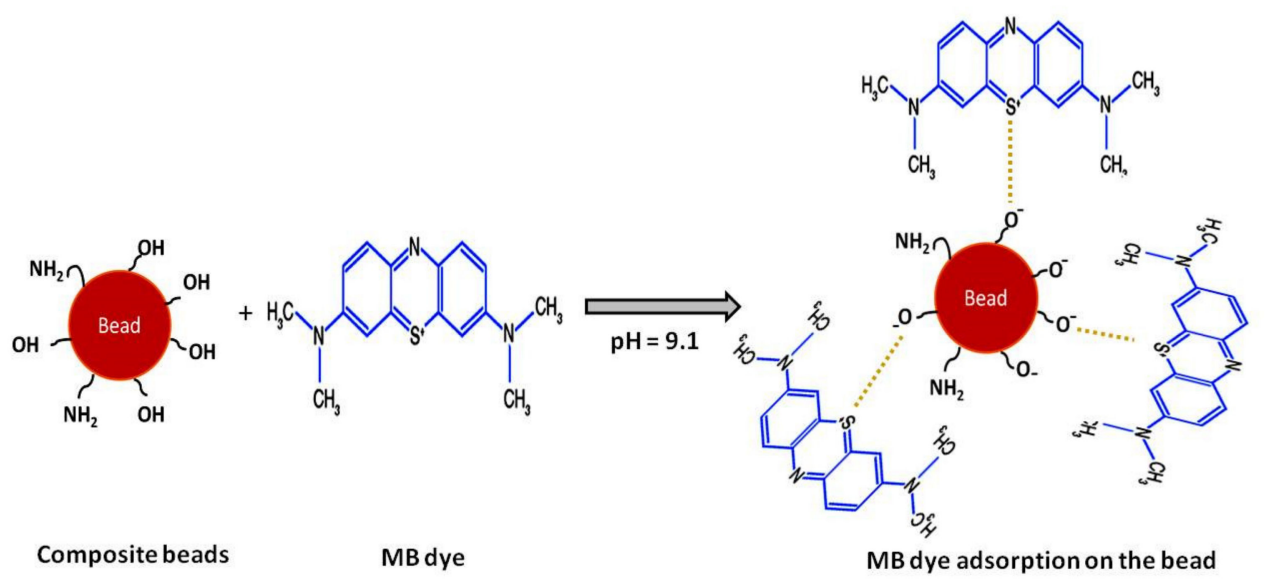

Figure 7. Proposed adsorption mechanism of methylene blue dye on composite beads.

Based on the adsorption analysis, in the case of the $\mathrm{Pb}$ (II) solution, with an increase in the available amine groups in the composite (from SB-1 to SB-3), the adsorption capacity was observed to increase. The lowest adsorption capacity among the composites was found for SB-5 (Table 2) (Figure 8). This composite was prepared by the addition of a higher percentage of chitosan compared to clay. Hence, higher amine groups from the chitosan were available, which in turn allowed for the formation of a co-ordination bond with the $\mathrm{Pb}^{2+}$ ion. In the case of SB-5, the percentage of clay was higher than that of the chitosan. Hence, fewer free amine sites were available for adsorbing $\mathrm{Pb}$ (II) ions. A detailed adsorption mechanism of $\mathrm{Pb}^{2+}$ ions on beads (both on the surface and in the interior part of the composite) has been illustrated in Figure 9. However, to understand the removal pattern of MB and $\mathrm{Pb}$ (II) from standard solution, a complete protocol of their isotherm studies is needed, which is currently ongoing in our research lab. 


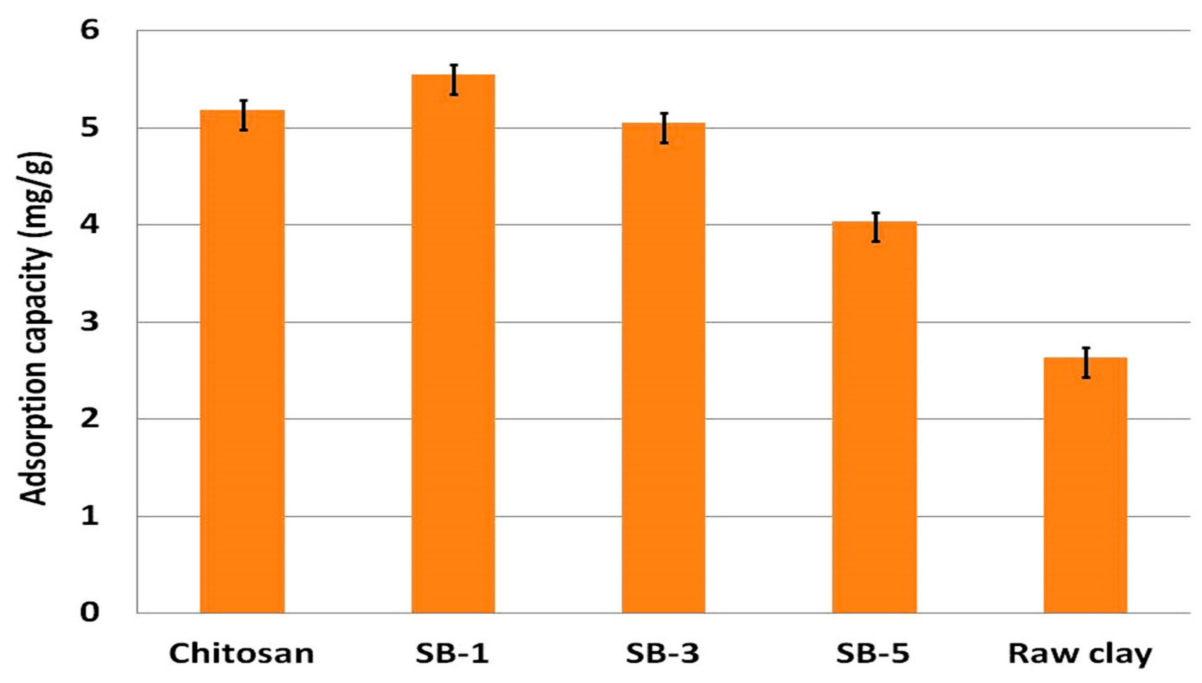

Figure 8. Removal of $\mathrm{Pb}$ (II) ions from standard solution by adsorbents.

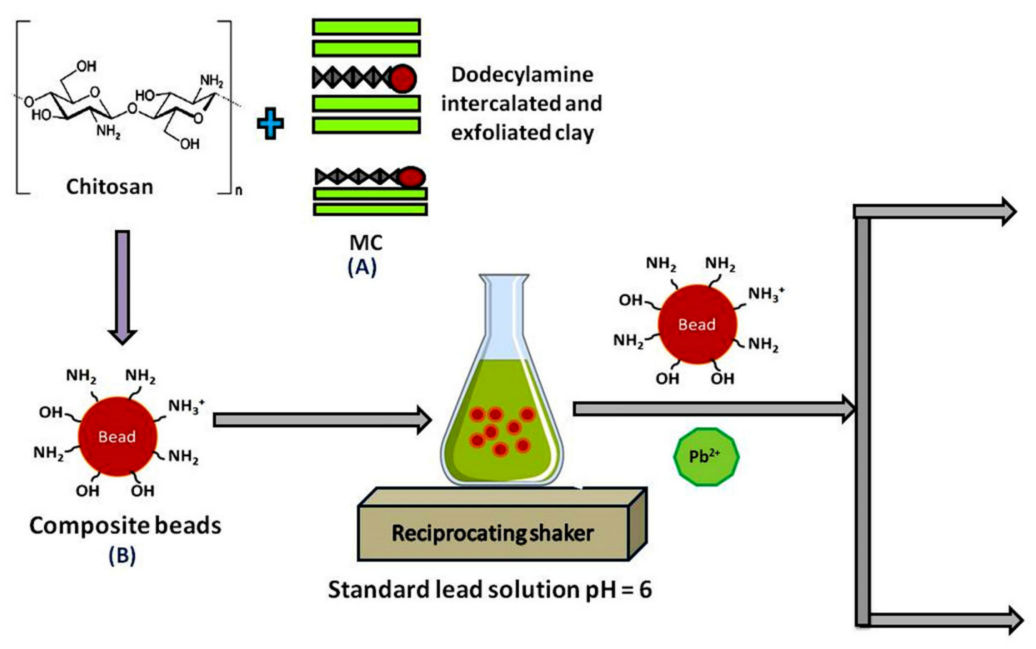

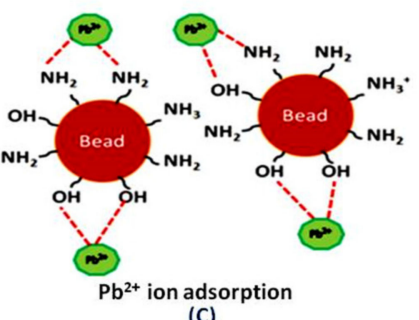

(C)

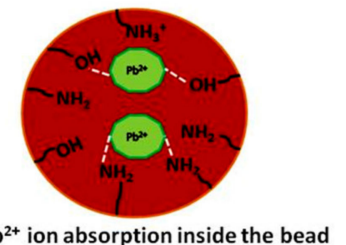

(D)

Figure 9. Proposed adsorption mechanism of $\mathrm{Pb}$ (II) on composite beads at $\mathrm{pH}=6$. (A) Dodecylamine molecules are intercalated or exfoliated on or within the clay structure and help to attach chitosan molecules to the clay. (B) Structure of bead showing $-\mathrm{NH}_{2}$ from chitosan and $-\mathrm{OH}$ from both chitosan and clay. (C) Adsorption of $\mathrm{Pb}^{2+}$ on bead surface interacting with $-\mathrm{NH}_{2}$ and $-\mathrm{OH}$. (D) Adsorption of $\mathrm{Pb}^{2+}$ within interior of beads.

\subsection{Preliminary Application of the Adsorbent in the Industrial Effluent}

\subsubsection{Removal of $\mathrm{Cr}(\mathrm{VI})$ and $\mathrm{Pb}$ (II) from Tannery Effluent}

The amount of chromium and lead in the original tannery sample was found to be $55 \mathrm{ppm}$ (the United States Environmental Protection Agency (EPA) approved ermissible limit for drinking water is $0.00001 \mathrm{ppm}$ ) and $40.5 \mathrm{ppm}$ (the EPA permissible limit for drinking water is $0.015 \mathrm{ppm}$ ), respectively, and was measured using a UV-visible spectrophotometer and AAS, respectively. The tannery sample was diluted to $0.110 \mathrm{ppm}$ for chromium and $0.081 \mathrm{ppm}$ for lead to match the instrument specifications. The adsorbent selected for effluent treatment was based on the results obtained from the standard solution adsorption. As the composite sample SB-1 showed the best adsorption performance for $\mathrm{Cr}(\mathrm{VI})$ and $\mathrm{Pb}$ (II), it was selected for the treatment of tannery effluent. After $2 \mathrm{~h}$ of treatment, the 
concentration was reduced to $0.054 \mathrm{ppm}$ for $\mathrm{Cr}$ (VI) and $0.049 \mathrm{ppm}$ for $\mathrm{Pb}$ (II). Hence, $50.90 \%$ of the $\mathrm{Cr}$ (VI) and $39.50 \%$ of the $\mathrm{Pb}$ (II) were removed from the tannery effluent (Table 3 ).

Table 3. Removal \% of heavy metals and dye from tannery and textile effluents.

\begin{tabular}{cccccc}
\hline \multirow{2}{*}{ Contaminants } & \multirow{2}{*}{ Effluents } & Composites & \multicolumn{2}{c}{ Concentration $(\mathbf{p p m})$} & \multicolumn{2}{c}{ Removal (\%) } \\
\cline { 4 - 5 } & & & Before $\left(\mathbf{C}_{\mathbf{b}}\right)$ & After $\left(\mathbf{C}_{\mathbf{a}}\right)$ & $\left(\left(\mathbf{C}_{\mathbf{b}}-\mathbf{C}_{\mathbf{a}}\right) / \mathbf{C}_{\mathbf{b}}\right) \times \mathbf{1 0 0 \%}$ \\
\hline $\mathrm{Cr}(\mathrm{VI})$ & Tannery & SB-1 & 0.110 & 0.054 & 50.90 \\
$\mathrm{~Pb}(\mathrm{II})$ & Tannery & SB-1 & 0.081 & 0.049 & 39.50 \\
$\mathrm{MB}$ & Textile & SB-5 & 0.190 & 0.130 & 31.50 \\
\hline
\end{tabular}

\subsubsection{Removal of Methylene Blue Dye from Textile Effluent}

The composite sample SB-5 was selected for the removal of methylene blue dye from real textile effluent. The initial concentration of MB in the effluent was found to be $0.19 \mathrm{ppm}$; the concentration decreased to $0.13 \mathrm{ppm}$ after treatment with composite beads. The percent removal was around $31 \%$ at slightly acidic $\mathrm{pH}$ (6) following a $2 \mathrm{~h}$ shaking period with the adsorbent.

\section{Discussion}

After analyzing all the above results, it can be inferred that the fabricated composites have potential applicability for industrial wastewater treatment. The removal percentage for $\mathrm{Pb}$ (II) and MB for the standard solution presented here is lower than that for $\mathrm{Cr}$ (VI) because these adsorption performances have not yet been optimized (Table 4 ). The results showed a lower value for removal percentages of $\mathrm{Cr}(\mathrm{VI}), \mathrm{Pb}$, and $\mathrm{MB}$ from real effluent (Table 3) compared to that from the standard solution (Table 4). The reason for this can be said to be the interference of other dissolved species present in real effluents like salts, surfactants, other dye molecules, and heavy metals, etc. Moreover, as the adsorption process was highly $\mathrm{pH}$-dependent, the deviation from standard $\mathrm{pH}$ for effluents was also responsible for this reduced performance. Some pretreatments used to exclude these interfering species, as well as adjust the $\mathrm{pH}$ for maximum adsorption efficiency, may increase the performance.

Table 4. Removal \% of heavy metals and dye from standard solution by the best selected composite.

\begin{tabular}{|c|c|c|c|c|}
\hline \multirow{2}{*}{ Contaminants } & \multirow{2}{*}{ Composites } & \multicolumn{2}{|c|}{ Concentration (ppm) } & \multirow{2}{*}{$\begin{array}{c}\text { Removal (\%) } \\
\left(\left(C_{b}-C_{a}\right) / C_{b}\right) \times 100 \%\end{array}$} \\
\hline & & Before $\left(C_{b}\right)$ & After $\left(C_{a}\right)$ & \\
\hline $\mathrm{Cr}(\mathrm{VI})$ & SB-1 & 25 & 5.21 & 67.16 \\
\hline $\mathrm{Pb}(\mathrm{II})$ & SB-1 & 25 & 11.13 & 55.48 \\
\hline $\mathrm{MB}$ & SB-5 & 25 & 14.85 & 40.60 \\
\hline
\end{tabular}

According to recent reports focusing on potential adsorbents (Table 5), more than 93\% of MB can be removed from wastewater by a chitosan-based composite, which is a much higher percentage than that relating to our composite under investigation [39]. In the case of removing $\mathrm{Pb}$ (II) from groundwater, maximum efficiency of $94 \%$ has been reported by Badmus et al. [40]. However, all these data were obtained under optimized conditions and present maximum efficiency. Our preliminary non-optimized studies show promising results compared to many other standard absorbents while removing the selected metal or dye ions. Optimizing the adsorption conditions (especially $\mathrm{pH}$, adsorbent dose, and the temperature used for obtaining maximum efficiency for chitosan-MC biocomposite beads) may make this composite competitive compared to all other adsorbents. 
Table 5. Comparison of the $\mathrm{Pb}$ (II) and MB removal percentages of composite beads with other commercial adsorbents.

\begin{tabular}{|c|c|c|c|c|c|c|}
\hline Metal/Dye & Adsorbents & Source & $\begin{array}{c}\text { Initial } \\
\text { Concentration } \\
(\mathrm{mg} / \mathrm{L})\end{array}$ & $\begin{array}{l}\text { Maximum } \\
\text { Sorption } \\
\text { Capacity } \\
\mathrm{Q}_{\max }(\mathrm{mg} / \mathrm{g}) \\
\end{array}$ & $\begin{array}{l}\text { Percentage } \\
\text { Removal } \\
\text { (\%) }\end{array}$ & Ref. \\
\hline \multirow{7}{*}{$\mathrm{Pb}$ (II) } & $\begin{array}{l}\text { Chitosan-coated } \\
\text { montmorillonite }\end{array}$ & Groundwater & 3 & - & 94.08 & [41] \\
\hline & $\begin{array}{l}\text { Activated periwinkle } \\
\text { shell carbon }\end{array}$ & Effluent ( $\mathrm{pH}$ 8.7) & 19.1 & - & 82.78 & \multirow[t]{2}{*}{ [40] } \\
\hline & $\begin{array}{l}\text { Commercial activated } \\
\text { carbon }\end{array}$ & Effluent ( $\mathrm{pH}$ 8.7) & 19.1 & - & 92.68 & \\
\hline & Chitosan & $\begin{array}{l}\text { Aqueous } \\
\text { solution }\end{array}$ & 100 & - & 50.30 & \multirow[t]{2}{*}{ [42] } \\
\hline & $\begin{array}{l}\text { Chitosan-manganese } \\
\text { dioxide }\end{array}$ & $\begin{array}{l}\text { Aqueous } \\
\text { solution }\end{array}$ & 100 & - & 88.70 & \\
\hline & \multirow[t]{2}{*}{$\begin{array}{l}\text { Chitosan-kaolinite rich } \\
\text { modified clay beads }\end{array}$} & $\begin{array}{l}\text { Aqueous } \\
\text { standard } \\
\text { solution }\end{array}$ & 25 & - & $55.48 *$ & \multirow[t]{2}{*}{$\begin{array}{l}\text { Present } \\
\text { study }\end{array}$} \\
\hline & & Tannery effluent & 0.081 & - & $39.50^{* *}$ & \\
\hline \multirow{5}{*}{ MB } & $\begin{array}{l}\text { Chitosan cross-linked } \\
\text { graphene } \\
\text { oxide/lignosulfonate } \\
\text { composite }\end{array}$ & $\begin{array}{l}\text { Aqueous } \\
\text { solution }\end{array}$ & 100 & 1023.9 & $>99 \%$ & [43] \\
\hline & $\begin{array}{l}\text { Chitosan-derived } \\
\text { three-dimensional porous } \\
\text { carbon }\end{array}$ & Wastewater & - & 925.93 & $>93.40$ & [39] \\
\hline & $\begin{array}{l}\text { Activated carbon from } \\
\text { apricot stones }\end{array}$ & $\begin{array}{l}\text { Aqueous } \\
\text { solution }\end{array}$ & 10 & - & 99.5 & [44] \\
\hline & \multirow[t]{2}{*}{$\begin{array}{l}\text { Chitosan-kaoline rich } \\
\text { modified clay beads }\end{array}$} & $\begin{array}{l}\text { Standard } \\
\text { solution }\end{array}$ & 25 & - & $40.60 *$ & \multirow[t]{2}{*}{$\begin{array}{l}\text { Present } \\
\text { study }\end{array}$} \\
\hline & & Textile effluent & 0.190 & - & $31.50^{* *}$ & \\
\hline
\end{tabular}

${ }^{*}$ Non-optimized condition for specific species removal from standard aqueous solution. ${ }^{* *}$ Non-optimized condition for specific species removal from effluent.

We are in the process of studying a detailed adsorption isotherm and the performance evaluation for $\mathrm{Pb}$ (II) and $\mathrm{MB}$ (as we did for $\mathrm{Cr}$ (VI)) and hope that the adsorption efficiency for these two species will be promising compared to other available adsorbents. We will present detailed outcomes in our next report.

\section{Conclusions}

From the present study, it can be concluded that the biocomposite beads of chitosan with modified Bijoypur clay act as a promising adsorbent to remove $\mathrm{Cr}$ (VI) and $\mathrm{Pb}$ (II) ions and methylene blue dye from both standard solution and real effluent. FTIR and XRD studies confirmed the successful formation of the composites. SEM micrographs clearly explained the surface morphology of the prepared composites. The composite which was rich in clay (SB-5) showed a better performance for cationic dye (MB) uptake, whereas heavy metals ( $\mathrm{Cr}(\mathrm{VI})$ and $\mathrm{Pb}(\mathrm{II})$ ) were better adsorbed on the SB-1 composite, which is rich in chitosan. In addition, adsorption studies were performed for real tannery and textile effluent showing a lower removal percentage compared to the standard solution. From tannery effluent, SB-1 can remove $50.90 \%$ of $\mathrm{Cr}$ (VI) and $39.50 \%$ of $\mathrm{Pb}$ (II) ions. A methylene blue dye removal efficiency of $31.50 \%$ was experienced in the case of textile effluent. The results suggest that a wide range of efficient composite formulations could be developed based on the adsorbates present in the effluent. However, a detailed study should be performed on the adsorption isotherm and adsorption efficiency of the composites for different heavy metals and dyes present in tannery effluent and textile effluent. 
Author Contributions: Conceptualization, M.M.R., P.H., and S.B.; methodology, S.B. and T.U.R.; software, S.B. and T.D.; validation, S.B. and T.U.R.; formal analysis, S.B., T.U.R., and T.D.; investigation, S.B.; resources, M.M.R. and P.H.; data curation, S.B. and T.U.R.; writing — original draft preparation, S.B.; writing-review and editing, S.B. and T.U.R.; visualization, S.B., T.U.R., and T.D.; supervision, M.M.R., P.H., and T.U.R; project administration, M.M.R.; funding acquisition, M.M.R. All authors have read and agreed to the published version of the manuscript.

Funding: This research was partially funded by the Organization for the Prohibition of Chemical Weapons (OPCW) (project account no. L/ICA/ICB/194479/14).

Acknowledgments: The authors highly acknowledge the Organization for the Prohibition of Chemical Weapons (OPCW) for their partial research grant. We also acknowledge the analytical and technical support provided by the Centre for Advanced Research in Sciences (CARS), the Bangladesh Atomic Energy Commission (BAEC), and the Bangladesh Council for Scientific and Industrial Research (BCSIR).

Conflicts of Interest: The authors declare no conflict of interest.

\section{References}

1. Balaji, V.; Datta, S.; Bhattacharjee, C. Evaluation on biological treatment for industrial wastewater. Biomed. Environ. Sci. 2005, 85, 320-326.

2. Kabir, S.; Rashid, T.U.; Negulescu, I.I. Gelation of Textile Dye Solution Treated with Fish Scales. Gels 2019, 5, 37. [CrossRef]

3. Islam, M.M.; Khan, M.N.; Biswas, S.; Choudhury, T.R.; Haque, P.; Rashid, T.U.; Rahman, M.M. Preparation and characterization of bijoypur clay-crystalline cellulose composite for application as an adsorbent. Adv. Mater. Sci 2017, 2, 1-7. [CrossRef]

4. Khan, M.N.; Luna, I.Z.; Islam, M.M.; Sharmeen, S.; Salem, K.S.; Rashid, T.U.; Zaman, A.; Haque, P.; Rahman, M.M. Cellulase in Waste Management Applications. In New and Future Developments in Microbial Biotechnology and Bioengineering; Elsevier: Amsterdam, The Netherlands, 2016; pp. 237-256.

5. Amin, M.; Dey, S.C.; Rashid, T.U.; Ashaduzzaman, M.; Shamsuddin, S.M. Solar assisted photocatalytic degradation of reactive azo dyes in presence of anatase titanium dioxide. Int. J. Latest Res. Eng. Technol. 2016, 2, 14-21.

6. Crini, G.; Lichtfouse, E. Advantages and disadvantages of techniques used for wastewater treatment. Environ. Chem. Lett. 2019, 17, 145-155. [CrossRef]

7. García-García, A.; Martínez-Miranda, V.; Martínez-Cienfuegos, I.G.; Almazán-Sánchez, P.T.; Castañeda-Juárez, M.; Linares-Hernández, I. Industrial wastewater treatment by electrocoagulation-electrooxidation processes powered by solar cells. Fuel 2015, 149, 46-54. [CrossRef]

8. Miklos, D.B.; Remy, C.; Jekel, M.; Linden, K.G.; Drewes, J.E.; Hübner, U. Evaluation of advanced oxidation processes for water and wastewater treatment-A critical review. Water Res. 2018, 139, 118-131. [CrossRef]

9. Bee, A.; Obeid, L.; Mbolantenaina, R.; Welschbillig, M.; Talbot, D. Magnetic chitosan/clay beads: A magsorbent for the removal of cationic dye from water. J. Magn. Magn. Mater. 2017, 421, 59-64. [CrossRef]

10. Crini, G.; Lichtfouse, E.; Wilson, L.D.; Morin-Crini, N. Adsorption-oriented processes using conventional and non-conventional adsorbents for wastewater treatment. In Green Adsorbents for Pollutant Removal; Springer: Cham, Switzerland, 2018; pp. 23-71.

11. Leal, T.W.; Lourenço, L.A.; Scheibe, A.S.; de Souza, S.M.G.U.; de Souza, A.A.U. Textile wastewater treatment using low-cost adsorbent aiming the water reuse in dyeing process. J. Environ. Chem. Eng. 2018, 6, 2705-2712. [CrossRef]

12. Shahzad, A. (Ed.) Green biocomposites from renewable biopolymers and their biomedical applications. In Biocomposites: Properties, Performance and Applications; Nova Science Publishers, Inc.: Hauppauge, NY, USA, 2017; pp. 473-541.

13. Crini, G.; Lichtfouse, E. Green Adsorbents for Pollutant Removal: Fundamentals and Design; Springer: Cham, Switzerland, 2018.

14. Desbrieres, J.; Guibal, E. Chitosan for wastewater treatment. Polym. Int. 2018, 67, 7-14. [CrossRef]

15. Rahman, M.M.; Rashid, T.U.; Datta, A. Chitosan: Process and Modification. In Encyclopedia of Biomedical Polymers and Polymeric Biomaterials; CRC Press: London, UK, 2015; Volume 11, pp. 1811-1825.

16. Rashid, T.U.; Islam, M.S.; Sharmeen, S.; Biswas, S.; Zaman, A.; Khan, M.N.; Mallik, A.K.; Haque, P.; Rahman, M.M. Applications of Chitosan Derivatives in Wastewater Treatment. In Handbook of Composites from Renewable Materials; John Wiley \& Sons, Inc.: Hoboken, NJ, USA, 2017; pp. 471-517. 
17. Dey, S.C.; Al-Amin, M.; Rashid, T.U.; Sultan, M.; Ashaduzzaman, M.; Sarker, M.; Shamsuddin, S. Preparation, characterization and performance evaluation of chitosan as an adsorbent for remazol red. Int. J. Latest Res. Eng. Technol. 2016, 2, 52-62.

18. Ahsan, S.M.; Thomas, M.; Reddy, K.K.; Sooraparaju, S.G.; Asthana, A.; Bhatnagar, I. Chitosan as biomaterial in drug delivery and tissue engineering. Int. J. Biol. Macromol. 2018, 110, 97-109. [CrossRef] [PubMed]

19. Qasim, S.B.; Zafar, M.S.; Najeeb, S.; Khurshid, Z.; Shah, A.H.; Husain, S.; Rehman, I.U. Electrospinning of chitosan-based solutions for tissue engineering and regenerative medicine. Int. J. Mol. Sci. 2018, $19,407$. [CrossRef] [PubMed]

20. Rahman, M.M.; Kabir, S.; Rashid, T.U.; Nesa, B.; Nasrin, R.; Haque, P.; Khan, M.A. Effect of $\gamma$-irradiation on the thermomechanical and morphological properties of chitosan obtained from prawn shell: Evaluation of potential for irradiated chitosan as plant growth stimulator for Malabar spinach. Radiat. Phys. Chem. 2013, 82, 112-118. [CrossRef]

21. Bayón, B.; Berti, I.R.; Gagneten, A.M.; Castro, G.R. Biopolymers from Wastes to High-Value Products in Biomedicine. In Waste to Wealth; Springer: Singapore, 2018; pp. 1-44.

22. Islam, M.S.; Haque, P.; Rashid, T.U.; Khan, M.N.; Mallik, A.K.; Khan, M.N.I.; Khan, M.; Rahman, M.M. Core-shell drug carrier from folate conjugated chitosan obtained from prawn shell for targeted doxorubicin delivery. J. Mater. Sci. Mater. Med. 2017, 28, 55. [CrossRef]

23. Zhang, L.; Zeng, Y.; Cheng, Z. Removal of heavy metal ions using chitosan and modified chitosan: A review. J. Mol. Liq. 2016, 214, 175-191. [CrossRef]

24. Biswas, S.; Rashid, T.U.; Mallik, A.K.; Islam, M.; Khan, M.N.; Haque, P.; Khan, M.; Rahman, M.M. Facile Preparation of Biocomposite from Prawn Shell Derived Chitosan and Kaolinite-Rich Locally Available Clay. Int. J. Polym. Sci. 2017, 6472131. [CrossRef]

25. Gu, S.; Kang, X.; Wang, L.; Lichtfouse, E.; Wang, C. Clay mineral adsorbents for heavy metal removal from wastewater: A review. Environ. Chem. Lett. 2019, 17, 629-654. [CrossRef]

26. Karathanasis, A.D. Clay Minerals: Weathering and Alteration of Encyclopedia of Soil Science; CRC Press: Boca Raton, FL, USA, 2017; pp. 430-434.

27. Oun, A.; Tahri, N.; Mahouche-Chergui, S.; Carbonnier, B.; Majumdar, S.; Sarkar, S.; Sahoo, G.C.; Amar, R.B. Tubular ultrafiltration ceramic membrane based on titania nanoparticles immobilized on macroporous clay-alumina support: Elaboration, characterization and application to dye removal. Sep. Purif. Technol. 2017, 188, 126-133. [CrossRef]

28. Ebrahimi, H.; Abedi, B.; Bodaghi, H.; Davarynejad, G.; Haratizadeh, H.; Conte, A. Investigation of developed clay-nanocomposite packaging film on quality of peach fruit (Prunus persica Cv. Alberta) during cold storage. J. Food Process. Preserv. 2018, 42, e13466. [CrossRef]

29. Martino, L.; Guigo, N.L.; van Berkel, J.G.L.; Sbirrazzuoli, N. Influence of organically modified montmorillonite and sepiolite clays on the physical properties of bio-based poly (ethylene 2,5-furandicarboxylate). Compos. Part B Eng. 2017, 110, 96-105. [CrossRef]

30. Biswas, S.; Islam, M.M.; Hasan, M.; Rimu, S.; Khan, M.; Haque, P.; Rahman, M. Evaluation of Cr (VI) Ion Removal from Aqueous Solution by Bio-Inspired Chitosan-Clay Composite: Kinetics and Isotherms. Iran. J. Chem. Eng. 2018, 15, 63-80.

31. Rashid, T.U.; Rahman, M.M.; Kabir, S.; Shamsuddin, S.M.; Khan, M.A. A new approach for the preparation of chitosan from $\gamma$-irradiation of prawn shell: Effects of radiation on the characteristics of chitosan. Polym. Int. 2012, 61, 1302-1308. [CrossRef]

32. Yano, K.; Usuki, A.; Okada, A.; Kurauchi, T.; Kamigaito, O. Synthesis and properties of polyimide-clay hybrid. J. Polym. Sci. Part A Polym. Chem. 1993, 31, 2493-2498. [CrossRef]

33. Wang, S.F.; Shen, L.; Tong, Y.J.; Chen, L.; Phang, I.Y.; Lim, P.Q.; Liu, T.X. Biopolymer chitosan/montmorillonite nanocomposites: Preparation and characterization. Polym. Degrad. Stab. 2005, 90, 123-131. [CrossRef]

34. American Public Health; American Water Works; Water Pollution Control; Water Environment. Standard Methods for the Examination of Water and Wastewater; American Public Health Association: Washington, DC, USA, 1915.

35. Deepali, K.K.; Gangwar, K. Metals concentration in textile and tannery effluents, associated soils and ground water. N. Y. Sci. J. 2010, 3, 82-89.

36. Li, Y.; Jin, Z.; Li, T.; Li, S. Removal of hexavalent chromium in soil and groundwater by supported nano zero-valent iron on silica fume. Water Sci. Technol. 2011, 63, 2781-2787. [CrossRef] 
37. Anah, L.; Astrini, N. Influence of $\mathrm{pH}$ on $\mathrm{Cr}(\mathrm{VI})$ ions removal from aqueous solutions using carboxymethyl cellulose-based hydrogel as adsorbent. In IOP Conference Series: Earth and Environmental Science; IOP Publishing: Bristol, UK, 2017; p. 012010.

38. Pandey, S.; Mishra, S.B. Organic-inorganic hybrid of chitosan/organoclay bionanocomposites for hexavalent chromium uptake. J. Colloid Interface Sci. 2011, 361, 509-520. [CrossRef]

39. Jin, Q.; Li, Y.; Yang, D.; Cui, J. Chitosan-derived three-dimensional porous carbon for fast removal of methylene blue from wastewater. RSC Adv. 2018, 8, 1255-1264. [CrossRef]

40. Badmus, M.; Audu, T.; Anyata, B. Removal of lead ion from industrial wastewaters by activated carbon prepared from periwinkle shells (Typanotonus fuscatus). Turk. J. Eng. Environ. Sci. 2007, 31, 251-263.

41. Tsai, W.-C.; Ibarra-Buscano, S.; Kan, C.-C.; Futalan, C.M.; Dalida, M.L.P.; Wan, M.-W. Removal of copper, nickel, lead, and zinc using chitosan-coated montmorillonite beads in single-and multi-metal system. Desalin. Water Treat. 2016, 57, 9799-9812. [CrossRef]

42. Anwar, Y. Antibacterial and lead ions adsorption characteristics of chitosan-manganese dioxide bionanocomposite. Int. J. Biol. Macromol. 2018, 111, 1140-1145. [CrossRef] [PubMed]

43. Yan, M.; Huang, W.; Li, Z. Chitosan cross-linked graphene oxide/lignosulfonate composite aerogel for enhanced adsorption of methylene blue in water. Int. J. Biol. Macromol. 2019, 136, 927-935. [CrossRef] [PubMed]

44. Djilani, C.; Zaghdoudi, R.; Djazi, F.; Bouchekima, B.; Lallam, A.; Modarressi, A.; Rogalski, M. Adsorption of dyes on activated carbon prepared from apricot stones and commercial activated carbon. J. Taiwan Inst. Chem. Eng. 2015, 53, 112-121. [CrossRef]

(C) 2020 by the authors. Licensee MDPI, Basel, Switzerland. This article is an open access article distributed under the terms and conditions of the Creative Commons Attribution (CC BY) license (http://creativecommons.org/licenses/by/4.0/). 